\begin{tabular}{l} 
POLITEIA/ POLITEIA: Jurnal Ilmu Politik \\
Politeia: Jurnal Ilmu Politik, 12 (1) (2020): 1-13 \\
ISSN 0216-9290 (Print), ISSN 2549-175X (Online) \\
Available online https:/ / talenta.usu.ac.id/politeia \\
\hline
\end{tabular}

\title{
Mencermati Populisme Prabowo Sebagai Bentuk Gaya Diskursif Saat Kampanye Politik Pada Pemilihan Presiden 2019
}

\author{
Alwi Dahlan Ritonga * \& Fernanda Putra Adela
}

Departemen Ilmu Politik, Universitas Padjadjaran, Bandung, Indonesia Departemen Ilmu Politik, Universitas Sumatera Utara, Medan, Indonesia

\begin{abstract}
Abstrak
Penelitian ini mengkaji tentang penggunaan populisme sebagai gaya diskursif salah satu calon presiden pada Pemilu 2019 di Indonesia yaitu Prabowo Subianto. Fenomena global yang menunjukkan munculnya kemenangan pemimpin-pemimpin populis di hampir seluruh dunia ternyata membuat Prabowo juga tertarik untuk memainkan gaya kepemimpinan populis untuk meraup simpati masyarakat. Prabowo memainkan isu populis ketika melakukan kampanye politik sebagai gaya diskursif. Retorika yang dilakukan oleh Prabowo ketika berkampanye sangat sarat dengan isu-isu populistik. Peneliti melakukan analisis dengan mengacu pada teori Cas Mudde (2007) yang mengemukakan karakteristik dari populisme terwujud dalam tiga ciri yaitu anti kemapanan (anti-establishment) atau anti elit, otoriterisme, dan nativisme. Objek penelitian ini terfokus pada Prabowo sebagai aktor politik yang sedang memainkan isu populisme sebagai gaya diskursif dengan mencermati konten-konten yang ia sampaikan ketika berkampanye. Teknik pengumpulan data menggunakan data-data sekunder berupa surat kabar, media cetak maupun kanal berita elektronik serta bahan lain yang mendukung penelitian. Data-data tersebut dianalisis dengan menggunakan pendekatan deskriptif-kualitatif. Hasil penelitian menunjukkan bahwa Prabowo memang hanya menggunakan populisme sebagai bentuk discursive style saja. Prabowo melakukan kampanye populis terkait "referensi kerakyatan", Prabowo terlihat secara tegas dan eksplisit membela rakyat dan melakukan perlawanan terhadap elit. Prabowo juga melakukan kampanye populis terkait "eksklusi kelompok lain". Akan tetapi, terkait "eksklusi kelompok lain" ini terlihat bahwa Prabowo tidak berani secara eksplisit dan terkesan kabur.
\end{abstract}

Kata Kunci: Gaya Diskursif, Kampanye Politik, Pemilu, Populisme

\begin{abstract}
Abstrak
This study examines the use of populism as a discursive style of one of the presidential candidates in the 2019 Election in Indonesia, Prabowo Subianto. The global phenomenon that shows the emergence of the victory of populist leaders in almost the whole world turned out to make Prabowo also interested in playing a populist leadership style to gain sympathy from the public. Prabowo plays a populist issue when conducting political campaigns as a discursive style. The rhetoric done by Prabowo when campaigning was very full of populistic issues. The researcher will carry out the analysis by referring to the theory of Cas Mudde (2007) who argues that the characteristics of populism manifest in three characteristics, namely antiestablishment or anti-elite, authoritarianism and nativism. The object of this research will be focused on Prabowo as a political actor who is playing the issue of populism as a discursive style by looking at the content he delivers when campaigning. Data collection techniques will use secondary data in the form of newspapers, print media and electronic news channels and other materials that support research. These data will be analyzed using a qualitative-descriptive approach. The results showed that Prabowo indeed only used populism as a form of discursive style. Prabowo conducted a populist campaign related to "popular reference", Prabowo was seen decisively and explicitly defending the people and fighting the elite. Prabowo also carried out a populist campaign related to "exclusion of other groups". However, regarding this "exclusion of other groups" it appears that Prabowo did not dare to be explicit and seemed to run away.

Password:Discursive Style, Election, Populism, Political Campaign
\end{abstract}

How to Cite: Ritonga, A. D. \& Adela, F. P. (2019). Mencermati Populisme Prabowo Sebagai Bentuk Gaya Diskursif Saat Kampanye Politik Pada Pemilihan Presiden, Politeia: Jurnal Ilmu Politik, 12 (1): 1-13

*Corresponding author:

E-mail: alwiedahlan@gmail.com 



\section{PENDAHULUAN}

Penelitian yang membahas tentang populisme di Indonesia sejak lama sudah menjadi salah satu diskursus yang memiliki tempat tersendiri bagi para sarjana ilmu politik. Jika dilihat secara historis, bahkan Soekarno pemimpin Indonesia pertama adalah sosok yang dikenal sebagai tokoh populis karena gaya retorikanya yang kharismatik dan selalu melontarkan perlawanan terhadap kolonialisme/imperialisme sehingga dia dicap sebagai penyambung lidah rakyat. Setelah Soekarno juga muncul beberapa pemimpin populis seperti Gus Dur yang muncul sebagai simbol perlawanan terhadap elit-elit Orde Baru dan membela hak-hak kaum marginal. Kemudian ada Megawati yang juga muncul sebagai tokoh perempuan populis karena selalu menggaungkan suara orang-orang lemah "Wong Cilik" (Zip, 2001). Buktibukti ini memperlihatkan bahwa populisme di Indonesia bukanlah merupakan sebuah barang baru karena sudah mengakar sejak lama.

Namun, jika dilihat secara lebih cermat, diskursus tentang populisme baru memiliki tempat yang lebih istimewa sejak kurang lebih satu dekade terakhir. Pada rentang waktu ini lah muncul banyak karya-karya para sarjana yang berfokus untuk mengulas tentang fenomena populisme di Indonesia (Anditya, 2017; Hadiz, 2015; Hadiz \& Robison, 2017; Kusumo \& Hurriyah, 2018; Liddle, 2019; Mietzner, 2009; Mudhoffir, Yasih, \& Hakim, 2017; Okamoto, 2009; Pratikno \& Lay, 2013). Tanpa bermaskud untuk mengesampingkan yang lain, menurut saya salah satu faktor yang menyebabkan kecenderungan tersebut adalah karena munculnya sosok Prabowo di panggung politik. Prabowo merupakan tokoh yang menjadi simbol populisme di Indonesia. Selain momentum global yang memang tengah mengalami gelombang populisme, momentum domestik seperti kemunculan Prabowo sedikit banyaknya juga pasti berpengaruh. Terdapat beberapa ahli yang mengidentifikasikan tokoh ini sebagai tokoh populis Indonesia seperti (Aspinal, 2014; Aspinall, 2015; Gueorguiev, Ostwald, \& Schuler, 2019; Hellmann, 2017; Kurlantzick, 2018; Mietzner, 2015). Dengan demikian, untuk memahami populisme di Indonesia, sedikit banyaknya bisa dipelajari dengan mengkaji Prabowo sebagai salah satu aktor politik.

Dengan demikian dapat dipahami bahwa ketika melakukan pembahasan mengenai populisme yang ada di Indonesia, maka akan selalu berbicara tentang Prabowo sebagai salah satu elemen yang cukup dominan dalam diskursus tersebut. Prabowo telah muncul sebagai bagian penting tentang populisme yang ada di Indonesia. Hal ini semakin kentara saat dia mengikuti kompetisi untuk mendapatkan jabatan presiden Indonesia untuk yang kedua kalinya. Pada tahun 2014, Prabowo maju melawan Jokowi untuk memperebutkan jabatan presiden. Saat itu keduanya sama-sama terlihat populis di depan rakyat. Seperti yang dikatakan oleh Mietzner (2015) bahwa Jokowi dan Prabowo sama-sama sosok yang populis hanya saja keduanya memiliki ciri populis yang berbeda. Jokowi muncul sebagai sosok populis 
teknokratik yang lebih soft ketimbang Prabowo yang muncul sebagai sosok populis klasik yang melakukan penentangan total terhadap sistem yang berkuasa. Pada pemilihan 2019, Prabowo tetap muncul sebagai representasi pemimpin yang populis, sementara Jokowi sangat sulit untuk di identifikasi sebagai sosok populis barangkali karena bertarung sebagai sosok petahana. Kondisi tersebut tentu mempengaruhi gaya kampanye dan strategi politik Jokowi di tahun 2019.

Oleh karena itu, peneliti merasa tertarik untuk membahas tentang bagaimana populisme Prabowo pada pemilihan presiden 2019. Peneliti melihat fenomena populisme Prabowo dengan sudut pandang gaya diskursif. Dengan demikian, penelitian ini akan berfokus kepada individu yaitu Prabowo sebagai aktor yang melakukan kegiatan politik. Peneliti mencermati gaya Prabowo dalam memainkan wacana populis ketika saat melakukan kampanye politik sepanjang masa kampanye pemilihan presiden 2019.

\section{METODE PENELITIAN}

Penelitian ini menggunakan metode kualitatif. Penetitian ini akan memakai jenis penelitian kualitatif deskriptif yang hanya akan melihat fenomena, lalu mengkajinya secara teoritis lalu menggambarkan fakta dan data yang ada di lapangan. Objek penelitian ini akan terfokus pada Prabowo sebagai aktor politik yang sedang memainkan isu populisme sebagai gaya diskursif dengan mencermati konten-konten yang ia sampaikan ketika berkampanye. Teknik pengumpulan data akan

menggunakan data-data sekunder berupa surat kabar, media cetak maupun kanal berita elektronik serta bahan lain yang mendukung penelitian dan nantinya dalam proses pengutipan dan pengumpulan data akan dicantumkan lengkap dengan nama surat kabar, tanggal terbit serta konten yang dimuat di dalamnya.

Peneliti melihat fenomena populisme Prabowo dengan sudut pandang discursive style lalu memakai teks, ucapan, wacana publik yang berkembang tentang politik sebagai unit analisis. Kemudian teks, ucapan atau wacana publik tersebut akan diinterpretasikan secara analitis. Elemen yang akan peneliti analisis adalah tiga elemen yang disampaikan oleh De Vreese yaitu (1) selalu merujuk kepada kata "rakyat" (2) perjuangan melawan elite "korup" dan dengan kemungkinan berlanjut kepada (3) pengidentifikasian terhadap sebuah out-group.

\section{HASIL DAN PEMBAHASAN}

Mendiskusikan teori tentang Populisme bukanlah hal yang mudah karena masih sangat sarat dengan perdebatan. Misalnya, masih dalam perdebatan apakah populisme merupakan ideologi atau bukan ? ada yang mengatakan bahwa populisme hanya ciri retorika dan bukanlah ideologi dalam arti yang serius. Ada juga yang menyematkannya kepada gaya kepemimpinan yang bersifat populer di tengah-tengah masyarakat (Laclau, 2005). Akan tetapi walaupun memiliki perdebatan teoritis, setidaknya terdapat semacam benang merah yang bisa dijadikan sebagai ciri 
umum dalam melihat konsepsi populisme.

Bahwa terdapat tiga ciri umum yang dimiliki oleh populisme yaitu anti establishment (anti kemapanan), autoritanism, dan nativisme. Antikemapanan dimaksudkan sebagai sebuah filsafat yang menekankan pada nilai kebijaksanaan dan kebajikan dari ordinary people atau the silent majority melawan berkuasanya para elit. Populisme mencerminkan sinisme mendalam dan kebencian kepada penguasa atau pejabat pemerintah yang ada. Ordinary people merupakan pihak homogen yang dianggap baik dan layak untuk menggantikan elite yang tidak jujur. (Mude, 2007)

Selanjutnya otoritarianisme dimaksudkan sebagai dukungan untuk memunculkan kekuatan personal yang diberikan kuasa kepemimpinan, memimpin dengan kuat dan karismatik sehingga dapat dianggap merepresentasikan kehendak rakyat. Sedangkan nativisme atau nasionalisme xenophobia yang mengasumsikan bahwa semua "orang" adalah kesatuan yang seragam atau homogen dengan identitas yang sama, di mana negara harus mengeksklusi orangorang dari negara dan budaya lain. Populisme monokulturalisme dari pada multikulturalisme, mendahulukan kepentingan nasional dari pada kerja sama internasional, menutup dan membatasi nilai-nilai liberal.

Dengan membaca Mudde, kita bisa memahami nilai yang menjadi ruh setiap gerakan yang dilakukan oleh kalangan populis. Dengan demikian, tiga kata kunci tersebut akan bisa dijadikan sebagai patokan dalam memeriksa konten yang akan dijadikan oleh Prabowo dalam setiap melakukan kampanye politik. Akan tetapi, untuk memahami populisme tidak semudah itu, seperti yang dikatakan diatas bahwa pengertian populisme sangat kompleks. Untuk itu, untuk memahami lebih rinci, maka peneliti akan memakai konsepsi yang dibuat oleh Noam Gidron dan Bart Bonikowski (2013) yang telah berhasil melakukan identifikasi terhadap populisme melalui kajian mendalam terhadap berbagai literatur yang ada. Mereka membuat varian terhadap populisme dengan mengkategorikannya terhadap tiga pendekatan konseptual utama. Ketiga pendekatan itu ialah:

\section{Populisme sebagai Ideologi}

Dalam bahasa lain, pendekatan ini juga bisa dibsebut sebagai pendekatan ideasional yaitu pendekatan yang lebih menekankan pada ide-ide atau gagasan yang disampaikan oleh aktor maupun kelompok populis. Dengan demikian, jika ideologi dianggap sebagai hal yang paling utama dari populisme, maka studi empirisnya harus mengarahkan perhatian peneliti terhadap "pernyataan programatik" yang dibuat oleh aktor politik dan memperlakukannya sebagai unit analisis utama.

\section{Populisme sebagai Gaya Diskursif}

Pendekatakan kedua ini dikonsepsi oleh Gidron dan Bart dengan merujuk salah satu sarjana yaitu de la Torre yang menganalisis 
fenomena populis di Amerika Latin memaksimalkan media-media kanal dan mendefenisikan populisme sebagai alternatif untuk menyuarakan sebuah "retorika" yang membangun kampanye. Michels Hasting dalam politik sebagai moral dan etika (Rahmah, 2019, p. 15) mengatakan perjuangan antara rakyat dan oligarki. bahwa populisme adalah sebuah gaya Masih dalam Gidron dan Bart, Kazin politik, dimana populisme muncul mengatakan bahwa retorika adalah sebagai sumber perubahan dengan bahasa yang digunakan untuk menggunakan retorika untuk menarik mengklaim bahwa ia mewakili suara rakyat. Bentuk yang diskursif tersebut mayoritas sehingga secara jelas dalam memiliki karakteristik kebijakan populisme selalau mendikotomikan programatik yang minimal, akan tetapi antara "kita" dan "mereka". Bagi memiliki simbol yang kuat, misalnya Kazin, populisme tidak bisa disebut saja mengenai isu ekonomi, agama, sebagai ideologi yang menunjukkan etnis, elit, dan lain-lain. (Rahmah, 2019) nilai yang dipegang oleh aktor politik melainkan hanya sekedar model ekspresi politik yang secara strategis dan selektif dengan pembedaan ideologi kiri atau kanan dan liberal atau konservatif. Rooduijn dkk dalam (Rahmah, 2019) mengatakan bahwa defenisi populism as a discursive style ini menjadi penting untuk digunakan sebagai kacamata melihat fenomena aktor politik. Definisi ini membuat sudut pandang terhadap populisme bukan lagi identitas ideologi seorang aktor politik melainkan political talk atau model ekspresi atau retorika. Aktor populis biasanya selalu berkomunikasi dengan bahasa yang sederhana yang dapat dipahami oleh orang biasa.

Komunikasi aktor populis dengan rakyat selalu menggunanakan komunikasi langsung. Aktor populis lebih memilih saluran komunikasi langsung seperti Televisi, Radio dan media sosial atau media-media lainnya. Bahkan mereka juga kerap menyerang media-media mainstream karena dianggap tidak netral sebab sudah terkontaminasi oleh intervensi penguasa. Hal itulah yang menyebabkan mereka lebih

\section{Populisme sebagai Strategi Politik}

Berbeda dengan pendekatan ideasional dan diskursif, beberapa sarjana menganjurkan pemahaman populisme sebagai mode strategi politik. Pendekatan ini, yang sangat lazim di kalangan sosiolog dan ilmuwan politik yang bekerja di Amerika Latin, terdiri dari tiga varian itu fokus pada berbagai aspek strategi politik: pilihan kebijakan, organisasi politik, dan bentuk mobilisasi (Gidron \& Bonikowski, 2013). Dalam pendekatan ini, populisme menjadi alat bagi aktor politik untuk mendapatkan, merebut, menjalankan atau mempertahankan kekuasaan. Jika pendektan ini digunakan untuk meninjau Prabowo, maka dirasa sangat kurang relevan karena Prabowo tidak sedang berkuasa atau sedang mempertahankan kekuasaan. 
Tabel 1. Karakteristik dari tiga pendekatan penelitian populisme

\begin{tabular}{|c|c|c|c|}
\hline Varian & $\begin{array}{l}\text { Defenition } \\
\text { of populism }\end{array}$ & $\begin{array}{l}\text { Unit of } \\
\text { analysis }\end{array}$ & $\begin{array}{l}\text { Relevant } \\
\text { methods }\end{array}$ \\
\hline $\begin{array}{l}\text { Politica } \\
1 \\
\text { ideolog } \\
\text { y }\end{array}$ & $\begin{array}{l}\text { A set of } \\
\text { interrelated } \\
\text { ideas about } \\
\text { the nature } \\
\text { of politics } \\
\text { and society }\end{array}$ & $\begin{array}{l}\text { Parties } \\
\text { and party } \\
\text { leaders }\end{array}$ & $\begin{array}{l}\text { Qualitative } \\
\text { or } \\
\text { automated } \\
\text { texts } \\
\text { analysis, } \\
\text { mostly of } \\
\text { partisan } \\
\text { literature }\end{array}$ \\
\hline $\begin{array}{l}\text { Politica } \\
1 \text { style }\end{array}$ & $\begin{array}{l}\text { A way of } \\
\text { making } \\
\text { claims } \\
\text { about } \\
\text { politics; } \\
\text { characteristi } \\
\text { cs of } \\
\text { discourse }\end{array}$ & $\begin{array}{l}\text { Texts, } \\
\text { speeches, } \\
\text { public } \\
\text { discourse } \\
\text { about } \\
\text { politics }\end{array}$ & $\begin{array}{l}\text { Interpretiv } \\
\text { e textual } \\
\text { analysis }\end{array}$ \\
\hline $\begin{array}{l}\text { Politica } \\
1 \\
\text { strateg } \\
y\end{array}$ & $\begin{array}{l}\text { A form of } \\
\text { mobilizatio } \\
n \quad \text { and } \\
\text { organizatio } \\
n\end{array}$ & $\begin{array}{l}\text { Parties } \\
\text { (with a } \\
\text { focus on } \\
\text { structures) } \\
\text { social } \\
\text { movement } \\
\text { s, leaders }\end{array}$ & $\begin{array}{l}\text { Comparati } \\
\text { ve } \\
\text { historical } \\
\text { analysis, } \\
\text { case } \\
\text { studies }\end{array}$ \\
\hline
\end{tabular}

Sumber tabel: Gidron \& Bonikowski, 2013

Dari tiga varian yang dikonseptualisasikan oleh Gidron dan Bart diatas, kita dapat melihat bagaimana cara kerja masing-masing pendekatan dalam melihat fenomena populisme. Ketiganya memiliki kekuatan masing-masing dalam meninjau fenomena. Dari tiga pendekatan tersebut, peneliti memakai varian yang kedua sebagai pendekatan untuk mencermati fenomena populisme yang dijalankan oleh Prabowo. Menurut peneliti, varian ini paling relevan dijadikan sebagai pendekatan karena lebih menggambarkan kasus yang sedang diteliti.
Setelah mengetahui nilai yang menjadi ruh gerakan kalangan populisme dan varian yang ada dalam konsepsi populisme, selanjutnya dibutuhkan semacam pegangan yang lebih spesifik untuk menganalisis kasus Prabowo. Karena penelitian ini mengkaji tentang gaya diskursif Prabowo pada saat melakukan kampanye politik, tentu akan bersinggungan dengan ranah komunikasi politik. Untuk itu, peneliti juga memakai teori yang disuguhkan oleh De Vreese, Esser, Aalberg, Reinemann, \& Stanyer (2018) cukup operasional dalam menganalisis suatu fenomena populisme. Diskursus sangat berkaitan erat dengan komunikasi politik, De Vreese dkk mendefenisikan bahwa "If we take the premise seriously that populism is a communication phenomenon, we can distinguish how three key actors - (1) political parties, (2) the media, and (3) citizens - relate to populism in their communication"(De Vreese et al., 2018, p. 5). Dari tiga unsur tersebut, peneliti hanya akan mengambil unsur pertama yaitu aktor politik untuk digunakan sebagai fokus dan objek analisis. Jika mengambil aktor politik sebagai fokus, maka manifestasi diskursus sang aktor akan terlihat dalam tiga elemen sentral yaitu: (1) selalu merujuk kepada kata "rakyat" (2) perjuangan melawan elite "korup" dan dengan kemungkinan berlanjut kepada (3) pengidentifikasian terhadap sebuah out-group (De Vreese et al., 2018, p. 5). Jika dicermati, sebenarnya tiga elemen ini merupakan elemenelemen yang hampir sama dengan yang telah disampaikan oleh Cas Mudde (Mudde, 2007). Dengan demikian maka peneliti akan lebih mudah untuk menganalisis kasus ini secara lebih baik. 


\section{POPULISME PRABOWO}

Prabowo Subianto adalah calon presiden yang disebut-sebut sebagai sosok yang sangat populistik (Aspinal, 2014). Dengan merujuk pendapat William Case, Lidle juga mengatakan bahwa Prabowo merupakan kandidat presiden yang populis (Liddle, 2019). Ditambah lagi, Prabowo juga didukung oleh Ijtima Ulama yang sejatinya merupakan kalangan Islam konservatif (islam sayap kanan) yang pernah menggulingkan Ahok. Dengan demikian, sudah tidak diragukan lagi bahwa Prabowo Subianto merupakan calon presiden yang sangat populistik.

Untuk melihat lebih jelas tentang populisme yang ada pada kubu Prabowo, penulis akan meminjam anatomi yang telah dibuat oleh Ari A. Perdana (2017). Berdasarkan tinjauan pemikiran yang ia lakukan terhadap beberapa ahli ditemukan bahwa setidaknya terdapat 3 (tiga) elemen ekspresi yaitu: Pertama, anti kemapanan atau anti elitisme, dalam arti mewakili ekspresi kelompok yang merasa termarjinalkan. Prabowo dalam beberapa kali pidatonya saat kampanye selalu menggaungkan isu elitisme yang korup dan mengakibatkan kesengsaraan terhadap rakyat seperti yang ia lakukan ketika di Stadion Kridosono Yogyakarta (Sabandar, 2019) ; kedua, adanya otoritas pemimpin, baik melalui kharisma atau figur personal maupun pesan yang bersifat apokaliptik "Negara kita bangkrut, Indonesia akan bubar". Ketiga perasaan in-group yang kuat, yang dalam banyak hal ditunjukkan dalam sentimen 'kita vs mereka' - garis pembatas bisa berdasarkan kelas atau status ekonomi
(Taipan, Naga Sembilan), penduduk vs imigran, bahkan ras dan agama (Partai Setan dan Partai Tuhan).

\section{REFERENSI KERAKYATAN PRABOWO DALAM KAMPANYE}

Tema tentang kerakyatan adalah tema yang selalu dilontarkan oleh Prabowo disetiap kampanyenya dengan retorika yang berapi-api. Hal ini tentu saja dilakukan agar mendapatkan citra bahwa Prabowo merupakan sosok yang sangat berpihak kepada "rakyat". Tema kerakyatan disampaikan dari tiga sudut.

Sudut pertama, Prabowo berpidato dengan mengungkapkan rasa simpatiknya secara individual terhadap rakyat dengan ungkapanungkapan verbal dan non-verbal seperti menggebrak meja ketika berpidato. Contohnya dengan menyampaikan bahwa niat Prabowo seutuhnya merupakan keterpanggilan nurani untuk membela rakyat dan jihad hidupnya karena usai bela rakyat dia akan siap dipanggil oleh tuhan juga ungkapan seperti "lebih baik saya hancur daripada rakyat menderita" dan "saya harusnya istirahat, tapi rakyat masih miskin"(Ansyari, 2019; CNN Indonesia, 2018; News.okezone.com, 2019; Utama, 2019).

Sudut kedua, dengan mengungkit rasa emosional rakyat dengan mengungkapkan keadaan rakyat dan negara seperti "kehidupan rakyat yang menderita", "Indonesia negara kaya tapi rakyatnya miskin", "rakyat menginginkan perubahan", "99\% rakyat hidup pas-pasan", "rakyat 
tidak bisa dibohong-bohongi lagi“", "untuk apa merdeka kalau sebagian rakyat tidak bisa makan" (Aco, 2019; Mardiastuti, 2018; Nasional.kontan.co.id, 2019; Paath, 2019; Sukoyo, 2019).

\section{Ketiga, Prabowo} mempertentangkan antara rakyat versus elit dengan menempatkan elit pada pihak yang sangat merugikan rakyat banyak. Pada bentuk ketiga ini, Prabowo selalu melontarkan pernyataan seperti "uang rakyat dicuri elit", "pertahanan negara rapuh akibat ulah elit", "elit Jakarta tidak pikirkan rakyat kecil", "rakyat dibohongi elit", "kekayaan negeri dikuasai 1 persen elit", "saya muak dengan elit-elit berengsek", "elit Jakarta bohongi rakyat dan menganggap rakyat bodoh", "elit-elit Jakarta adalah bajingan" (Alamijaya, 2019; Anggriawan, 2019; Drajad, 2019; Meilisa, 2019; Sabandar, 2019; Sugiyarto, 2019; Waspada.co.id, 2019).

Pada intinya, referensi kerakyatan ini digunakan untuk menarik simpati rakyat banyak dengan memunculkan simpatisme dengan melontarkan slogan-slogan retoris. Prabowo mengkonfrontasikan antara rakyat dengan elit dimana rakyat dianggap sebagai kelompok mayoritas yang dikendalikan oleh segelintir elit yang amoral dan koruptif.

\section{EKSKLUSI “KELOMPOK-LAIN”}

Setelah melakukan pembelaan terhadap rakyat disatu sisi, dan mengungkapkan realitas rakyat yang terpuruk, kemudian melakukan perlawanan terhadap para elit di sisi lain maka selanjutnya adalah melakukan upaya untuk memisahkan antara keduanya (eksklusi) untuk menimbulkan rasa in-groups yang kuat. Cara ini secara tidak langsung menyebabkan pembelahan terhadap rakyat dan memperkuat rasa identitas. Menurut Caroline, pembentukan identitas mencakup proses konstruksi pembedaan-pembedaan dan pertentangan-pertentangan untuk menentukan batasan antara "insiders" dengan "outsiders", antara diri dan yang liyan (Paskarina, 2017, p. 291).

Elemen ini mencakup referensi dan pengecualian terhadap kelompokkelompok luar (kelompok yang tidak termasuk populisme). Perspektif komunikasi politik menyatakan bahwa membangun rasa identitas sosial tertentu adalah jantung dari populisme. Pesan komunikatif yang dapat menjadi aspek utama bagi identitas sosial adalah dengan mendefenisikan bahwa in-groups sebagai kelompok orang-orang baik (bermoral), dan membangun narasi bahwa out-groups sebagai kelompok minoritas yang bermasalah, elit yang mementingkan diri sendiri, dan disajikan sebagai kambing hitam yang mengancam. Namun, yang jelas bahwa identifikasi out-groups bukanlah fitur yang selalu ada pada semua jenis populisme, tetapi retorika out-groups sering digunakan oleh populis kiri (melawan kapitalisme) dan kanan (melawan imigran, asing, antekantek)(De Vreese et al., 2018).

Lalu bagaimana dengan Prabowo ketika melakukan kampanye ? upaya untuk membelah atau mendikotomi rakyat ini juga secara implisit dilakukan oleh Prabowo ketika melakukan kampanye. Hal ini bisa 
diperiksa dari beberapa pidato yang ia sampaikan terhadap peserta kampanye seperti yang ia lakukan ketika di Yogyakarta dengan sangat berapi-api dan ditambah dengan menggebrak meja mengatakan sebagai tentara dan polisi rakyat, tidak boleh membela segelintir orang. "Apalagi antek-antek asing,"(CNN Indonesia, 2019). Kemudian seperti yang dilansir oleh merdeka.com tentang pernyataanpernyataan keras Prabowo soal antek asing seperti pernyataan bahwa "kekayaan Indonesia bukan untuk bangsa lain", "merdeka supaya tak jadi antek asing" dan "Yang tidak dukung Sandiaga Uno antek asing, saudarasaudara!"(Ningrum, 2018). Ungkapan antek asing adalah ungkapan yang sangat eksklusioner karena tidak hanya memisahkan identitas antar warga negara dengan warga negara lain tetapi lebih jauh telah memisahkan antara warga negara dengan kelompok yang berada di pihak negara lain.

Akan tetapi, untuk elemen ini terlihat bahwa Prabowo tidak berani berbicara secara eksplisit sebagaimana ketika ia membicarakan tentang rakyat dan elit. Bahkan terlihat seperti ada ke tidak-konsistenan Prabowo dalam menyikapi isu asing. Belakangan dia sering berkata bahwa dirinya tidak anti terhadap asing setelah mendapat kritikan dari lawan politiknya. Fakta inilah kemudian yang memperkuat argumentasi bahwa Prabowo memang hanya menjadikan populisme sebagai retorika saja atau gaya diskursif. Ketidak-konsistenan ini memperlihatkan bahwa Prabowo tidak secara ideologis menjalankan populisme tetapi bisa berubah-ubah tergantung opini publik (Tempo.co, 2018). Peneliti melihat bahwa Prabowo memang berada di ranah abu-abu tekait elemen ini. Eksklusi out-groups tidak ditemukan secara eksplisit dan terang dari Prabowo. Untuk menemukannya justru harus melihat orang-orang sekitarnya atau para pendukungnya yang secara terangterangan melakukan proses eksklusi seperti yang dilakukan oleh Amien Rais dengan membuat dikotomi antara pendukung "partai setan" vs "partai Allah" (Maharani, 2018)

\section{SIMPULAN}

Hasil penelitian menemukan bahwa Prabowo menjadikan populisme hanya sebagai gaya retorika dalam menarik simpati rakyat. Setelah melakukan pemeriksaan dengan menelusuri data-data sekunder maka peneliti menemukan bahwa Prabowo memang memainkan populisme sebagai discursive style pada pemilihan presiden 2019. Pada elemen pertama terkait referensi kerakyatan, Prabowo secara terang dan eksplisit mengkampanyekan tentang isu kerakyatan dan perlawanan terhadap elit. Akan tetapi, pada elemen eklsusi kelompok lain, terlihat ke-kaburan dalam kampanye Prabowo. Tidak terlihat bahwa Prabowo melakukan eksklusifikasi secara eksplisit melainkan hanya secara implisit bahkan terlihat ketidakkonsistenan pada persoalan kata "asing". Untuk memeriksanya justru harus melihat kepada orang-orang disekitarnya dan para pendukungnya yang jelas-jelas telah melakukan pembelahan atau dikotomi antara "kita" dan "mereka".

Kemudian, dengan masuknya Prabowo dalam jajaran kabinet Jokowi Periode ke-2. Maka argumentasi artikel 
ini semakin kuat. Dengan demikian, maka semakin terlihat bahwa Prabowo tidak menjadikan populisme sebagai basis idealisme ketika maju pada pilpres 2019. Populisme hanya sebatas gaya retorika yang digunakan untuk menarik simpati masyarakat.

\section{DAFTAR PUSTAKA}

\section{Artikel dalam jurnal ilmiah}

Aspinall, E. (2015). Oligarchic populism: Prabowo Subianto's Challenge to Indonesian Democracy. Cornell University Press, 99, 1-28. https://doi.org/10.5728/indonesia.99.0 001

De Vreese, C. H., Esser, F., Aalberg, T., Reinemann, C., \& Stanyer, J. (2018). Populism as an Expression of Political Communication Content and Style: A New Perspective. The International Journal of Press/Politics 1, 23(4), 423-438. https://doi.org/10.1177/1940161218790 $\underline{035}$

Gidron, N., \& Bonikowski, B. (2013). Varieties of Populism: Literature Review and Research Agenda. Weatherhead Working Paper Series, (No. 13-0004), 0-38. https://doi.org/10.2139/ssrn.2459387

Gueorguiev, D., Ostwald, K., \& Schuler, P. (2019). Rematch: Islamic Politics, Mobilisation, and the Indonesian Presidential Election. Political Science, 70(00), 1-13. https://doi.org/10.1080/00323187.2019. $\underline{1584733}$

Hadiz, V. R., \& Robison, R. (2017). Competing Populisms in Post-authoritarian Indonesia. International Political Science Review, 38(4), 488-502.

Kusumo, R., \& Hurriyah, H. (2018). Populisme Islam di Indonesia: Studi Kasus Aksi Bela Islam oleh GNPF-MUI Tahun 20162017. Jurnal Politik, 4(1), 87-144. https://doi.org/10.7454/jp.v4i1.172
Mudhoffir, A. M., Yasih, D. W. P., \& Hakim, L. (2017). Populisme Islam dan Tantangan Demokrasi di Indonesia. Prisma, 36(3), 48-59.

Paskarina, C. (2017). Narasi Identitas Populis dalam Demokrasi Elektoral. Jurnal Bawaslu, 3(2), 285-297.

Zip, D. (2001). Populist Perceptions and Perceptions of Populism in Indonesia The Case of Megawati Soekarnoputri. South East Asia Research, 9(1), 73-88.

\section{Buku teks}

Creswell, J. . (2013). Research Design: Pendekatan Kualitatif, Kuantitatif dan Mixed. Yogyakarta: Pustaka Pelajar.

Hadiz, V. R. (2015). Islamic Populism in Indonesia and the Middle East. Cambridge: Cambridge University Press.

Hellmann, O. (2017). Populism in East Asia. In C. R. Kaltwasser, P. Taggart, P. O. Espejo, \& P. Ostiguy (Ed.), The Oxford Handbook of Populism (hal. 161-178). New York: Oxford University Press.

Laclau, E. (2005). On Populist Reason. London: Verso.

Mietzner, M. (2009). Indonesia's 2009 Elections: Populism, Dynasties and the Consolidation of the Party System. Sydney: Lowy Institute for International Policy.

Mietzner, M. (2015). Reinventing Asian Populism: Jokowi's Rise, Democracy, and Political Contestation in Indonesia. Honolulu: East- -West Center.

Mudde, C. (2007). Populist Radical Right Parties in Europe. New York: Cambridge University Press.

Okamoto, M. (2009). Populism under Decentralization in Post- -Suharto Indonesia. In M. Kosuke \& P. Pasuk (Ed.), Populism in Asia (hal. 144-164). Singapore: NUS Press. 
Alwi Dahlan Ritonga \& Fernanda Putra Adela, Mencermati Populisme Prabowo Sebaga

Pratikno, \& Lay, C. (2013). From Populism to Democratic Polity: Problems and Challenges in Solo, Indonesia. In $\mathrm{K}$. Stokke \& O. Törnquist (Ed.), Democratization in the Global South: The Importance of Transformative Politics (hal. 254-276). London: Palgrave Macmillan.

Rahmah, A. N. N. (2019). Pasang Surut Populisme: Satu Dekade Populisme Basyir Ahmad di Pekalongan. Yogyakarta: Penerbit PolGov.

\section{Artikel dalam surat kabar/majalah umum}

Aco, H. (2019). Prabowo: Untuk Apa Merdeka Kalau Sebagian Rakyat Tidak Bisa Makan? Diambil 7 Juli 2019, dari Tribunnews.com website: https://www.tribunnews.com/pilpres2019/2019/02/23/prabowo-untuk-apamerdeka-kalau-sebagian-rakyat-tidakbisa-makan

Adhitia, F. B. (2018). Prabowo: Nasib Suatu Bangsa Tergantung Emak-emak. Diambil 7 Juli 2019, dari IDN Times website:

https://www.idntimes.com/news/ind onesia/fitang-adhitia/prabowo-nasibsuatu-bangsa-tergantung-emak-emak

Alamijaya, J. (2019). Prabowo Sebut Kekayaan Negeri Dikuasai 1 Persen Elite, Sandiaga Uno: Saya \& Prabowo Masuk Elit itu. Diambil 8 Juli 2019, dari kaltim.tribunnews.com website: https:// kaltim.tribunnews.com/2019/0 2/28/prabowo-sebut-kekayaan-negeridikuasai-1-persen-elite-sandiaga-unosaya-prabowo-masuk-elit-itu

Anggriawan, R. D. (2019). Prabowo: Elit Negeri Pinter Mencuri Uang Rakyat, Pinter Ngapusi. Diambil 8 Juli 2019, dari nasional.tempo.co website: https://nasional.tempo.co/read/117582 2/prabowo-elit-negeri-pinter-mencuriuang-rakyat-pinter-ngapusi

Ansyari, S. (2019). Prabowo: Usai Bela Rakyat, Saya Siap Dipanggil Allah. Diambil 7 Juli 2019, dari www.msn.com website: https://www.msn.com/id- id/berita/pemilu/prabowo-usai-belarakyat-saya-siap-dipanggil-allah/arBBURMU5

CNN Indonesia. (2018). Prabowo: Saya Harusnya Istirahat, Tapi Rakyat Masih Miskin. Diambil 7 Juli 2019, dari CNN Indonesia website: https://www.cnnindonesia.com/nasio nal/20181023040928-32-

340564/prabowo-saya-harusnyaistirahat-tapi-rakyat-masih-miskin

CNN Indonesia. (2019). Aksi Gebrak Podium Prabowo saat Bicara Antek Asing di Yogya. Diambil 9 Juli 2019, dari CNN Indonesia website: https://www.cnnindonesia.com/nasio nal/20190409064003-32-384455/aksigebrak-podium-prabowo-saat-bicaraantek-asing-di-yogya

Detikcom. (2018). Pidato "Tampang Boyolali" Prabowo yang Mendadak Viral. Diambil dari

https://www.youtube.com/watch?relo $\mathrm{ad}=9 \& \mathrm{v}=$ Xe681c7kzFU

Drajad. (2019). Prabowo Tuding Pertahanan Negara Rapuh Akibat Ulah Elit. Diambil 8 Juli 2019, dari www.harianumum.com website:

https://www.harianumum.com/baca/ prabowo-tuding-pertahanan-negararapuh-akibat-ulah-elit

Erdianto, K. (2019). Prabowo: Kalau EmakEmak Berpolitik, Pasti Revolusioner.

Maharani, T. (2018). Dituding Main Isu Identitas, TKN Ungkit "Partai Allah" dan "Partai Setan." Diambil 9 Juli 2019, dari news.detik.com website: https://news.detik.com/berita/d4364621/dituding-main-isu-identitastkn-ungkit-partai-allah-dan-partai-setan

Mardiastuti, A. (2018). Prabowo Sebut 99\% Rakyat Indonesia Hidup Sangat Paspasan. Diambil 7 Juli 2019, dari news.detik.com website: https://news.detik.com/berita/d4264516/ prabowo-sebut-99-rakyatindonesia-hidup-sangat-pas-pasan 
Meilisa, H. (2019). Prabowo Sindir Elite di Jakarta Tidak Pikirkan Rakyat Kecil. Diambil 8 Juli 2019, dari news.detik.com website: https://news.detik.com/berita-jawatimur/d-4491465/prabowo-sindir-elitedi-jakarta-tidak-pikirkan-rakyat-kecil

Nasional.kontan.co.id. (2019). Prabowo: Rakyat kita sudah tidak bisa dibohongbohongi lagi. Diambil 7 Juli 2019, dari nasional.kontan.co.id website: https://nasional.kontan.co.id/news/pr abowo-rakyat-kita-sudah-tidak-bisadibohong-bohongi-lagi

News.okezone.com. (2019). Ungkapkan Kecewa terhadap Elit Politik, Prabowo Gebrak Mimbar. Diambil 8 Juli 2019, dari news.okezone.com website: https://news.okezone.com/read/2019/ 04/08/605/2040641/ungkapkankecewa-terhadap-elit-politik-prabowogebrak-mimbar

Ningrum, D. A. (2018). Pernyataan-pernyataan Keras Prabowo Soal Antek Asing. Diambil 9 Juli 2019, dari merdeka.com website:

https://www.merdeka.com/politik/pe rnyataan-pernyataan-keras-prabowosoal-antek-asing/singgung-antek-asingsaat-pilkada-dki-jakarta.html

Paath, C. K. (2019). Prabowo: Rakyat Indonesia Ingin Perubahan. Diambil 7 Juli 2019, dari www.beritasatu.com website: https://www.beritasatu.com/politik/5 47286/prabowo-rakyat-indonesia-inginperubahan

Sabandar, S. (2019a). Prabowo Muak dengan Elite di Jakarta: Mereka Adalah Bajingan-Bajingan. Diambil 8 Juli 2019, dari www.liputan6.com website: https://www.liputan6.com/pilpres/rea d/3936820/prabowo-muak-denganelite-di-jakarta-mereka-adalah-bajinganbajingan

Sabandar, S. (2019b, April 8). Prabowo Muak dengan Elite di Jakarta: Mereka Adalah Bajingan-Bajingan. liputan6.com. Diambil dari https://www.liputan6.com/pilpres/rea d/3936820/prabowo-muak-denganelite-di-jakarta-mereka-adalah-bajinganbajingan

Sugiyarto. (2019). Prabowo Sebut Banyak Elit di Jakarta Bohongi Rakyat dan Menganggap Rakyat Bodoh. Diambil 8 Juli 2019, dari www.tribunnews.com website: https://www.tribunnews.com/pilpres2019/2019/03/31/prabowo-sebutbanyak-elit-di-jakarta-bohongi-rakyatdan-menganggap-rakyat-bodoh

Sukoyo, Y. (2019). Prabowo: Indonesia Negara Kaya, Tapi Rakyatnya Miskin. Diambil 7 Juli 2019, dari www.beritasatu.com website:

https://www.beritasatu.com/politik/5 32534/prabowo-indonesia-negara-kayatapi-rakyatnya-miskin

Tempo.co. (2018). Hashim Djojohadikusumo: Prabowo - Sandiaga Tidak Anti-Asing. Diambil 9 Juli 2019, dari Tempo.co website:

https://pilpres.tempo.co/read/1138177 /hashim-djojohadikusumo-prabowosandiaga-tidak-anti-asing

TribunNews.com. (2018). Ribuan Warga Turun ke Jalan Protes Pernyataan Prabowo soal "Tampang Boyolali." Diambil 7 Juli 2019, dari Tribunnews.com website: https://www.tribunnews.com/regional /2018/11/05/ribuan-warga-turun-kejalan-protes-pernyataan-prabowo-soaltampang-boyolali

Utama, F. (2019). Prabowo: Lebih Baik Saya Hancur Daripada Rakyat Menderita. Diambil 7 Juli 2019, dari iNews.ID website:

https://www.inews.id/news/nasional /prabowo-lebih-baik-saya-hancurdaripada-rakyat-menderita/498345

Waspada.co.id. (2019). Prabowo: Saya Muak Dengan Elit-Elit Brengsek Itu. Diambil 8 Juli 2019, dari waspada.co.id website: http://waspada.co.id/pemilu/prabowo -saya-muak-dengan-elit-elit-brengsekitu/ 
Alwi Dahlan Ritonga \& Fernanda Putra Adela, Mencermati Populisme Prabowo Sebaga

Artikel online (internet) tanpa tempat terbit dan penerbit

Anditya, N. R. (2017). Populisme Sayap Kanan di Negara-negara Demokratis: Kembalinya Yang-Politis. In Institut of International Studies Universitas Gajah Mada. Diambil dari http://hi.fisipol.ugm.ac.id/iis_brief/iss ue06-2017/

Aspinal, E. (2014). Prabowo dan Bahaya Terhadap Demokrasi Indonesia. Diambil dari Indoprogress.Com website:

https://indoprogress.com/2014/07/pr abowo-dan-bahaya-terhadapdemokrasi-indonesia/

Kurlantzick, J. (2018). Southeast Asia's Populism Is Different but Also Dangerous. Diambil 7 Juli 2019, dari Council on Foreign Relations website: https://www.cfr.org/article/southeastasias-populism-different-also-dangerous

Perdana, A. A. (2017). Menguatnya Populisme: Trump, Brexit hingga FPI. Diambil 27 Mei 2019, dari Indoprogress.Com website:

https://indoprogress.com/2017/01/me nguatnya-populisme-trump-brexit-

hingga-fpi/ 